AMSTERDAM EXPEDITIONS TO THE WEST INDIAN ISLANDS, REPORT $5 *$ )

\title{
NOTODIAPTOMUS CAPERATUS, A NEW CALANOID COPEPOD FROM PHREATIC GROUNDWATER IN BARBUDA (CRUSTACEA: DIAPTOMIDAE)
}

\author{
by \\ THOMAS E. BOWMAN \\ Department of Invertebrate Zoology, Smithsonian Institution, Washington, DC 20560, U.S.A.
}

\begin{abstract}
Notodiaptomus caperatus n. sp., from a well in Barbuda, is described and illustrated. It is the first diaptomid from the Lesser Antilles and the first West Indian diaptomid having affinities with South American species.
\end{abstract}

\section{INTRODUCTION}

Recently Dr. Jan H. Stock (Zoölogisch Museum, University of Amsterdam) sent to me for study a sample of calanoid copepods that he had collected in phreatic groundwaters of Barbuda, the northeasternmost of the Leeward Islands of the Lesser Antilles. The copepods proved to be the new diaptomid described below, the first from the Lesser Antilles.

\section{TAXONOMIC PART}

\section{Notodiaptomus caperatus $\mathrm{n} . \mathrm{sp}$.}

Figs. 2-4.

Material examined. - Sta. 78/19, University of Amsterdam Expeditions to the West Indian Islands. Barbuda, Guava Farm, S.E. of Codrington $\left(17^{\circ} 37^{\prime} 39^{\prime \prime} \mathrm{N} 61^{\circ} 48^{\prime} 51^{\prime \prime} \mathrm{W}\right)$, (fig. 1), from round, almost covered well, water table at $3 \mathrm{~m}$, depth of water $0.75 \mathrm{~m}$, chlorinity $1400 \mathrm{mg} / \mathrm{l}$, leg. J. H. Stock, 9 April 1978: 30 के के (holotype in Zoölogisch Museum Amsterdam (ZMA), coll. no. ZMA Co. 102.655a; 19 paratypes, ZMA Co. $102.655 \mathrm{~b}$; 10 paratypes in United States National Museum, Washington DC (USNM) coll. no. USNM 172318; 12 \% $\$$ (10 paratypes, ZMA Co. 102.655c; 2 paratypes, USNM 172318); 45 copepodids of various stages (ZMA Co. 102.655d).

*) Report no. 4 appeared in Verslagen en technische gegevens, Instituut voor Taxonomische Zoölogie (Zoölogisch Museum), Universiteit van Amsterdam, no. 20.
Description. - Female: Length 1.6-1.7 $\mathrm{mm}$. In dorsal view body widest at posterior cephalosome and pediger 1 , gradually narrowing posteriorly. Pedigers 4 and 5 separate. Pediger 5 produced into small wings; left wing directed slightly obliquely, armed with 2 conical spines; right wing directed nearly laterad, armed with 2 conical spines.

Urosome 2-merous, most or all of 2nd segment telescoped into genital segment. Genital segment nearly $1.5 \times$ as long as rest of urosome; anterior part expanded laterally into lobe on either side; right lobe with steeper sides, bearing conical spine at summit; left lobe with unarmed summit, but with conical spine at posterior base. In lateral view genital segment produced into posteroventral pouchlike protuberance, anterior to which are several vertical folds. Caudal ramus symmetrical, slightly more than half as wide as long.

Antenna 1 reaching slightly beyond caudal rami; segments 11-21 each with 1 seta. Antenna 2 with inner and outer lobes of endopod with 9 and 7 setae respectively. Maxilliped with lobes of 1 st basipod well developed; 4th lobe with only 3 setae and row of spinules on distal margin.

Legs 1-4 with normal armature of spines and setae. Leg 2 with triangular cuticular lobe on posterior surface of 2nd endopod segment.

Leg 5, 1st basipod with prominent posterior conical spine; 2nd basipod with short lateral seta. First exopod segment $2 \times$ as long as wide. Second exopod segment without lateral seta; claw moderately stout, armed on middle parts of both margins with close-set spinules. Third exopod segment slightly longer than wide; medial seta fused to 


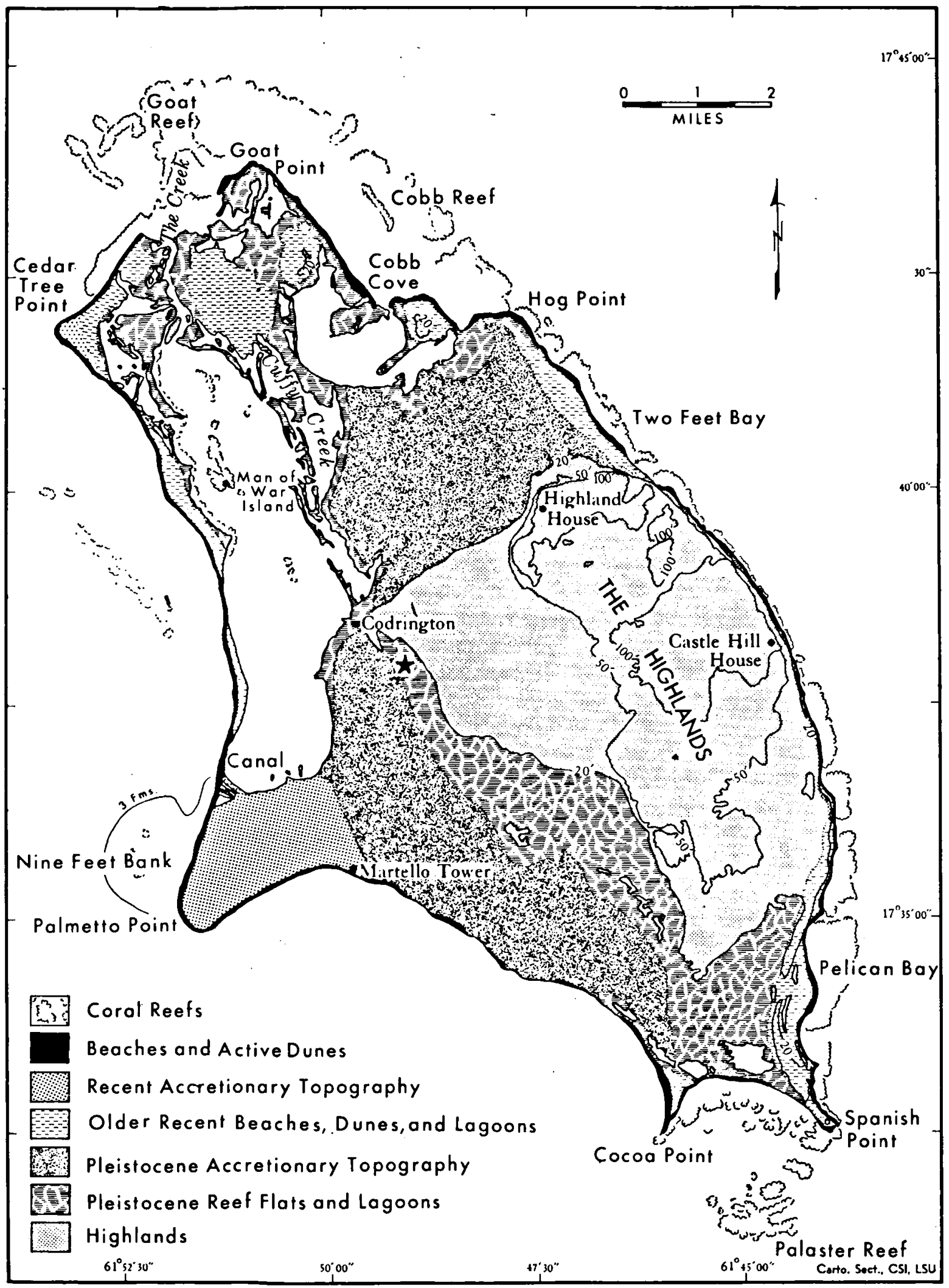

Fig. 1. Map of Barbuda (from Russell \& McIntire, 1966) showing the location of station 78/19 (indicated by a star), where Notodiaptomus caperatus n. sp. was collected. 


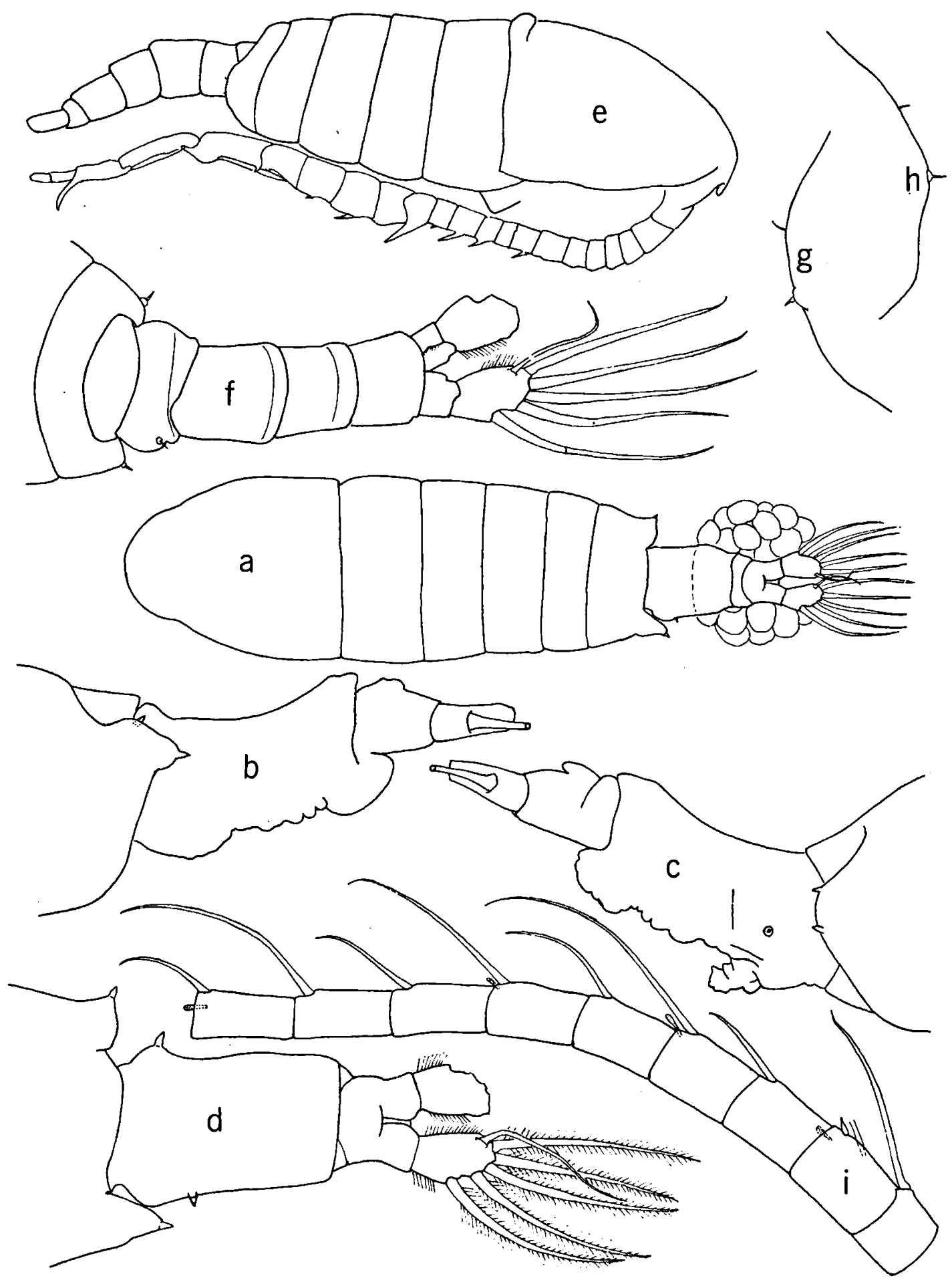

Fig. 2. Notodiaptomus caperatus n. sp.: a, $\$$, dorsal; b, $q$ pediger 5 and urosome, left side; c, same, right side; d, same, dorsal; e, $\hat{\delta}$, lateral; $f$, $\hat{\delta}$ pediger 5 and urosome, dorsal; $g$, $\hat{\delta}$ right wing of pediger 5 , lateral; h, $\hat{\delta}$ left wing of pediger 5 , lateral; $i$, $q$ antenna 1 , segments 11-19. 
segment at base, more than $2 \times$ length of lateral seta. Endopod reaching beyond middle of 1 st exopod segment, 2-merous; 2nd segment longer than 1st, distal margin oblique, armed with row of fine setae.

Male: Length 1.4-1.5 mm. Prosome shape as in female. Right posterior corner of pediger 5 rounded; left corner slightly angular; both corners armed with terminal spinule-tipped knob having setule dorsal to it. Genital segment asymmetrical, with higher bulge on left side bearing posterodorsal seta. Posterior part of urosome curved to right.

Right antenna 1 with spines on segments 8, 10, $11,12,13,15$, and 16. Spines on segments 10 and 11 subparallel to axis of antenna, those of segment 12 and especially 16 quite small, that of segment 13 suberect, large, with slightly incised tip. Segment 23 with strong recurved spinous process more than half length of segment.

Right leg 5, 1st basipod with moderately developed sensillum-bearing process. Second basipod about $1.5 \times$ longer than $1 \mathrm{st}$; medial margin with cuticular thickening at midlength; distomedial part of posterior surface with crescentic patch of fine hairs. Second exopod segment about $1.5 \times$ longer than 1 st and $1.6 \times$ longer than wide, with rounded knob at base medially; lateral spine subterminal, more than half length of segment; terminal claw nearly a third longer than exopod, gently arched with recurved tip. Endopod 2merous, not quite reaching midlength of 1 st exopod segment; apical margin oblique, armed with row of setules.

Left leg 5 slightly more slender than right, reaching about midlength of 1 st exopod segment of right leg. First basipod about $1 / 4$ longer than 2nd. Exopod with widely separated proximal and distal pads. Proximal pad slightly smaller than distal, bilobed. Distal process subconical, medial margin nearly straight and denticulate in distal part, lateral margin with bend near midlength. Proximal process straight, slender, pointed, medial margin with a few minute spinules.

Endopod reaching base of distal pad, becoming slightly narrower distally; apex slightly oblique, armed with row of slender setules.
Etymology. - From the Latin caperatus meaning wrinkled, referring to the folds on the female genital segment.

Relationships. - The Barbudan diaptomid is provisionally assigned to the South American genus Notodiaptomus Kiefer, 1936, which corresponds to the nordestinus group of Wright (1935). The limits of South American diaptomid genera have not been established firmly, and future revisionary studies may alter the generic assignment of the Barbudan species.

As with other diaptomids, $N$. caperatus may be identified by a combination of distinguishing characters rather than by one or two characters. The shape and armature of pediger 5 and the genital segment, the armature of antenna 1 in both sexes, and the structure of leg 5 in both sexes, taken together, will distinguish $N$. caperatus from other diaptomids. Perhaps the most striking characteristics are the wrinkled genital segment in the female, and the shape and denticulate inner margin of the distal process of the left leg 5 exopod in the male.

\section{HABITAT}

Barbuda is "hollow as Swiss cheese" (J. H. Stock, in litt.) and has substantial underground water, but no surface streams. Rainfall averages nearly $100 \mathrm{~cm} /$ year, with a recorded maximum of nearly $670 \mathrm{~cm}$ in 1913 and a minimum of about $55 \mathrm{~cm}$ in 1930. The water table is high, within $6 \mathrm{~m}$ of the surface on practically all lowland parts of the island. Two of the major wells provide more than 300,000 and 94,000 1/day (data from MartinKaye, 1956). The water is rather saline; MartinKaye (1956) gives measurements for salinity between 352 and $2865 \mathrm{ppm}(=\mathrm{mg} / \mathrm{l}$ ) for the major wells. Larger underground bodies of water surface exist in a number of caves, but none of those sampled contained calanoids.

Some diaptomids prefer small, temporary bodies of water, e.g. Hemidiaptomus amblyodon (Marenzeller) (see Dussart, 1967: 108, who terms such species "telmatoplanktonic"). However, I am not aware of any other diaptomid known only from 


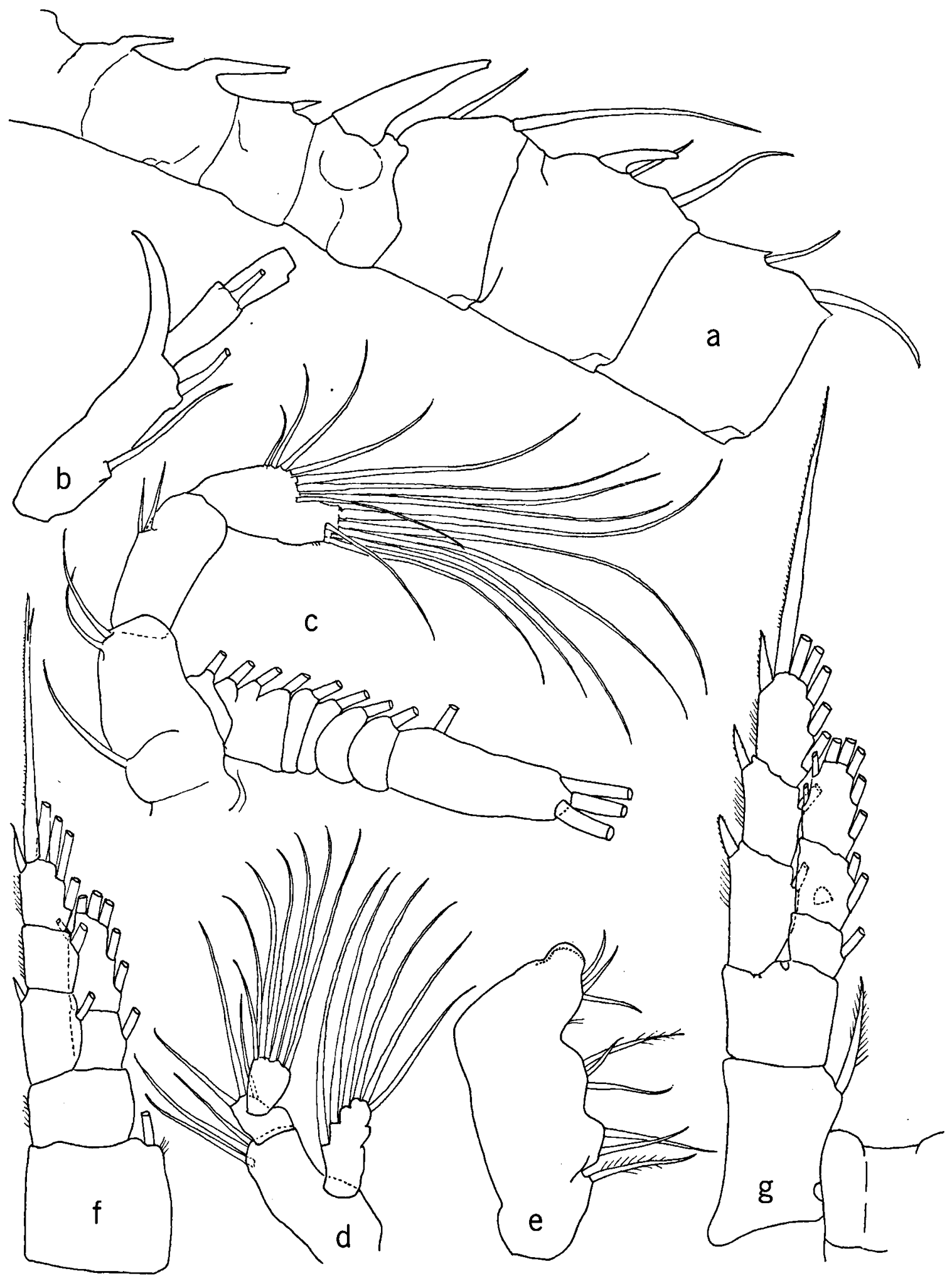

Fig. 3. Notodiaptomus caperatus n. sp.: a, of right antenna 1 , segments $10-16 ; b$, same, segment 23 ; , 9 antenna 2 ; d, $q$ mandibular palp; e, + maxilliped, 1st basipod; $f, q \operatorname{leg} 1 ; g, \& \operatorname{leg} 2$. 


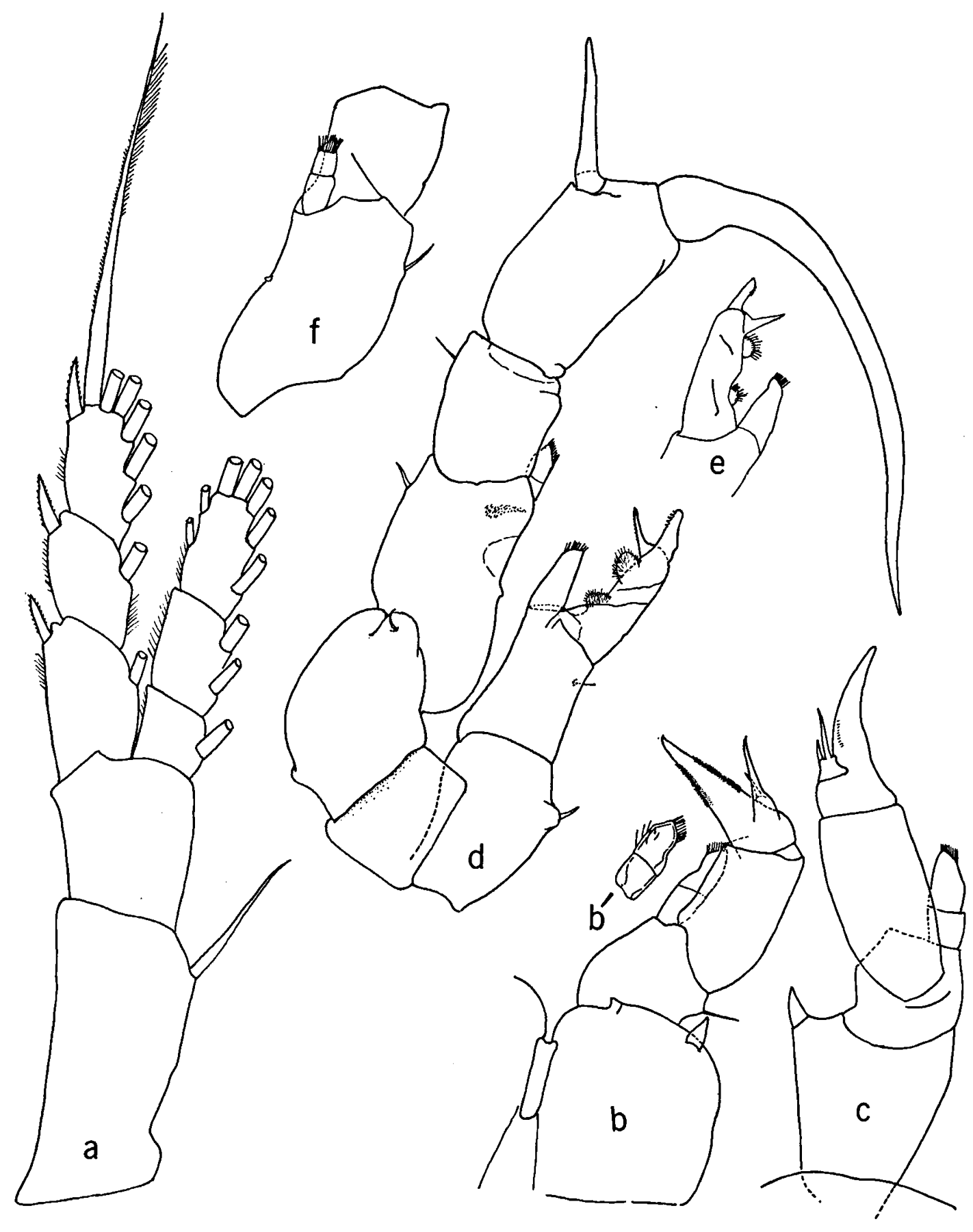

Fig. 4. Notodiaptomus caperatus n. sp.: a, $q$ leg 4; b, $\&$ leg 5, posterior; b', endopod of same, anterior; $c$, $\&$ leg 5 , lateral; d, ô leg S, posterior; e, ô left leg 5 , anterior; f, ô right leg 5, 2nd basipod, 1st exopod, and endopod, anterior. 
phreatic groundwater. C. B. Wilson (1936) reported Diaptomus albuquerquensis Herrick and D. novamexicanus Herrick from underground waters of Yucatan, but in open-air cenotes. Only one described diaptomid, the blind unpigmented Diaptomus cokeri Osorio-Tafall, 1942, from Cueva Chica and Cueva de los Sabinos, San Luis Potosi State, Mexico, appears to be a true troglobite, but at least some epigean diaptomids are able to live in underground waters. I have identified Diaptomus dorsalis Marsh, an epigean species of the southern and southwestern United States, Haiti, and Cuba, from phreatic groundwater in Cueva Grande de Caguanes, Cayo Caguanes, Las Villas Province, Cuba, where it was collected by L. Botosaneanu during the Cubano-Romanian Biospeleological Expeditions.

In phreatic waters diaptomids obviously cannot feed on phytoplankton, the usual food for most Diaptomidae, but phytoplankton is not essential to all members of this family. For example, $E u$ diaptomus gracilis (Sars) can survive for long periods by feeding on bacterial and organic detritus (Nauwerck, 1962). N. caperatus may have a similar diet, and in addition might possibly obtain some food by predation. Anderson (1970) has shown that Diaptomus arcticus Marsh, D. nevadensis Light, and $D$. shoshone Forbes, while not obligate predators, can catch fairly large and active prey and eat them efficiently. However, six other diaptomid species studied by Anderson were entirely herbivorous.

\section{ZOOGEOGRAPHY}

The three species of Diaptomidae thus far known from the West Indies have been found only on the Greater Antilles: Diaptomus proximus Kiefer, 1936 (= D. dorsalis Marsh, fide M. S. Wilson, 1959) from Haiti and Cuba; D. asymmetricus Marsh, 1907, and D. purpureus Marsh, 1907, from Cuba. These three species have been assigned to North American subgenera (M. S. Wilson, 1959). The two latter species are known only from Cuba, but $D$. dorsalis occurs in Louisiana and Florida (M. S. Wilson, 1959), Oklahoma (Robertson, 1970), and Arizona (Cole, 1961).
Until now, no diaptomids have been reported from the Lesser Antilles, and the presence of a diaptomid on Barbuda is remarkable, considering that the Amsterdam Expeditions sampled 580 stations on 29 islands for stygobionts and obtained calanoids only at 1 of the 16 stations on Barbuda. In contrast to the other West Indian diaptomids, $N$. caperatus has affinities with South American rather than North American species.

How $N$. caperatus arrived at Barbuda can only be conjectured. Some diaptomids can produce resistant eggs that withstand desiccation and could be transported considerable distances on waterfowl or even insects. Invasion of subterranean waters would necessarily be preceded by establishment in surface waters, which could have been present in Barbuda before the present karst features developed.

Attempts to explain the presence of $N$. caperatus by vicariance will have to take into consideration the youth of Barbuda, which is composed of Pleistocene limestones and calcarenites plus Recent accretions (Martin-Kaye, 1959). At times when Pleistocene seas were lowered because of accumulation of continental ice, the Barbuda Bank, which underlies Barbuda and Antigua, emerged but the Expedition did not find any diaptomids in Antigua groundwaters (15 stations sampled).

A vicariance model might suggest that at some time in the past an ancestral diaptomid was widespread in the Lesser Antilles and northern South America, but now survives in the Lesser Antilles only as a relict population. A cautionary note, however: $N$. caperatus is not widespread, being collected at only 1 of 16 stations in Barbuda, and its failure to turn up in collections from the other islands could reflect its rarity rather than its absence from them.

\section{ACKNOWLEDGEMENTS}

I am most grateful to Dr. Jan H. Stock for sending me the diaptomids and collection data and to Dr. Louis S. Kornicker for a helpful review of the manuscript.

The fieldwork in the various West Indian Islands has been supported by various subventions (to J. H. Stock): three grants of the Netherlands Foundation for the Advancement of Tropical Research (WOTRO), The Hague (WR 87-79, 87-114, and 87-144), two grants of the Treub Maatschappij, Utrecht (1976 and 1978), and a grant of the BeijerinckPopping Fonds, Amsterdam (1977). 


\section{REFERENCES}

ANDERSON, R. S., 1970. Predator-prey relationships and predation rates for crustacean zooplankters from some lakes in western Canada. Can. J. Zool., 48 (6): 12291240.

Cole, G. A., 1961. Some calanoid copepods from Arizona with notes on congeneric occurrences of Diaptomus species. Limnol. Oceanogr., 6 (4): 432-442.

Dussart;' B., 1967. Les Copépodes des eaux continentales d'Europe occidentale, I. Calanoïdes et Harpacticoïdes: 1-500 (N. Boubée \& Cie, Paris).

KIEFER, F., 1936. Über die Systematik der südamerikanischen Diaptomiden (Crustacea Copepoda). Zool. Anz., 116 (7/8): 194-200.

MarSH, C. D., 1907. A revision of the North American species of Diaptomus. Trans. Wis. Acad. Sci. Arts Lett., 15 (2): 381-516, pls. XV-XXVIII.

MARTIN-KAYE, P. H. A., 1956. The water resources of Antigua and Barbuda, B.W.I.: 1-109 (B. G. Lithographic Co., La Penitence, British Guyana).

1959. Reports on the geology of the Leeward and British Virgin Islands: 1-117, maps (Governor Leeward Islands, St. Lucia).
NAUwercK, A., 1962. Nicht-algische Ernährung bei Eudiaptomus gracilis (Sars). Arch. Hydrobiol., Suppl., 25 (4): 393-400.

Osorio-Tafall, B. F., 1942. Diaptomus (Microdiaptomus) cokeri, nueva subgénero y especie de Diaptomido de las cuevas de la región de Valles (San Luis Potosí, México). Ciencia Méx., 3 (7): 206-210.

RoberTSON, A., 1970. Distribution of calanoid copepods (Calanoida, Copepoda) in Oklahoma. Proc. Okla. Acad. Sci., 50: 98-103.

Russell, R. J. \& W. G. MCINTTRE, 1966. Barbuda reconnaissance. Louisiana State Univ, coastal Stud. Inst., Tech. Rep., 11 (J): i-viii, 1-53.

Wilson, C. B., 1936. Copepods from the cenotes and caves of the Yucatan Peninsula, with notes on cladocerans. Publs. Carnegie Instn., 457: 77-88.

Wilson, M. S., 1959. Calanoida. In: W. T. EDMONDSON ed., Ward and Whipple's fresh-water biology: 738-794 (John Wiley \& Sons, New York).

WRIGHT, S., 1935. Three new species of Diaptomus from northeast Brazil. Anais Acad. bras. Cienc., 7 (3): 213233, pls. I-IV. 